\title{
THE ROLE OF MANAGEMENT INFORMATION SYSTEM IN IMPROVING ORGANIZATIONAL PERFORMANCE AND EFFECTIVENESS IN CASE OF DEBRE MARKOS CITY ADMINISTRATION REVENUE AUTHORITY, ETHIOPIA
}

\author{
Getachew Alene \\ Department of Management Studies, Jinka University, Ethiopia
}

\begin{abstract}
The study was conducted on the role of management information system in enhancing effectiveness in Debre Markos city administration revenue authority and the total population of this organization is 76 since the total population was low the researcher used census method this means all the total population in the organization becomes the sample size of the research. So, the researcher was prepared enough questionnaires for each respondent. The main objective of this study was to assess how the information runs in the organization and evaluate organizational performance and effectiveness. The researcher was used descriptive type of research design. The study was used both primary and secondary source of data. In case of primary sources the researcher was used questionnaires and interview. In case of secondary source the researcher also used annual magazines of the organization and published and unpublished documents. The data was being analyzed using descriptive method and recommended the solution for the identified problems and opportunities to improve the organization's performance and effectiveness.
\end{abstract}

Keywords:

Management Information System, Revenue Authority, Debre Markos

\section{INTRODUCTION}

Every organization develops its own MIS which is totally dependent on the personal needs of the organizations. In the management information system not only the system itself is important but to get the maximum advantages from the system human intelligence, perception and from the system it is important that the human intelligence, perception and judgment must be powerful and strong enough to get combined with the system information. This combination will provide managers with the unique and valuable to and for the information management in any company. MIS is presently the organization nerves system which responds to opportunities and threats are avoided. It is widely acknowledged that firms with the best and most effective information system are those that have clear and well through of information strategy. In private organizations, MIS are important factors in assuring the competitive advantage and eventual profitability of the firm. On the other hand in governmental organizations MIS are just as crucial but from another perspective, in terms of responsiveness, efficiency, and productivity.

MIS provides information that manage organization effectively and efficiently. MIS in that they are used to analyze operational activities in the organization. Academically the term is commonly used to refer the group of information management methods tied to automation or support of human decision making. MIS is not only indicating how things are going but why and where things are operated.
The successful support of MIS in business long-term plan providing reports based on performance analysis and to face high competition. According to O'Brien [9], MIS is subset of the overall internal control of a business covering the application of people, documents, technologies and procedures by management accountants as to solving business problem. MIS is a system process which provides information need to manage organizations effectively. It helps to reduce organization's cost and useless amount of human power. Management information system (MIS) is different from regular information. System in that it is used to analyze other information systems, planned operational activities in the organization

\subsection{STATEMENT OF THE PROBLEM}

Currently the effectiveness of the organization directly related to the appropriate management information system. MIS provides managers with reports and in some cases, on line access to the organization current performance and historical data records. Management information system (MIS) produces information products that support many of the day to day decision making needs of managers and business professional reports, displays provide information products satisfy the information needs of decision make at the operational and tactical level of organization who are faced with more structured types of decision situations.

Most of organizations mainly depend up on MIS to process, record store and manipulate accurate data and information for the existence as well as profitability of the organization in processing data into accurate and well defined data, however without applying MIS organization does not have values for profit oriented as well as no profit firms. MIS needs to be strategically managed soaps to bring about sound and profitable organization and thereby increase organizational effectiveness of surviving to increase competitive advantage, to avoid challenges.

This study therefore, seeks to fill this knowledge gap by investigating the role of MIS in improving organization performance and effectiveness in case of Debre Markos city administration revenue authority. The reason that the researchers initiate to study about the role of MIS of the organization is to set objectives and to help once, to know more about the role of MIS. To reflect the advantage of MIS since MIS is important for the effectiveness of the organization the importance of knowing that MIS is most effect vend efficient that could generate higher level of effectiveness to the organization organizational effectiveness depend up on the role of MIS.

Therefore, in this study the researcher is emphasizing on the role of MIS in improving organization performance and effectiveness in Debre Markos city administration revenue authority. 


\subsection{RESEARCH QUESTIONS}

- The researcher in this journal tried to fill this gap by raising the following basic research questions.

- What are the roles of management information system in the organization?

- Does management information system enhance organizational performance and effectiveness?

- How does management information system support decision making process in the organization?

- What are the challenges regarding application of management information system in the organization?

\subsection{OBJECTIVES OF THE STUDY}

- The general objective of the study is to address the role of management information system in improving organizational performance and effectiveness in Debre Markos city administration revenue authority. The specific objectives of this article were:

- To investigate the roles of management information system in the organization.

- To explore the management information system contributes to the organizational performance and effectiveness.

- To evaluate the effectiveness of MIS in supporting decision making process.

- To identify challenges that hinders the application of MIS in the organization.

\section{LITERATURE REVIEW}

There is a lot of research on the approaches, techniques and technologies for the design and development of MIS. However, there are a few articles that cover the impact of Management Information Systems on planning strategies and decision making. While there are no universally accepted definitions of MIS and those that exist in literatures are just prejudices of the researchers [2]. MIS is a system or process that provides information needed to manage organizations effectively. Additionally, MIS is a development, use and application of information systems by individuals, organizations and society". An information system as "a system consisting of the network of all communication channels used within an organization". In their study, Laudon and Laudon [7] have defined MIS as "the study of information systems focusing on their use in business and management". The abovementioned definitions showed that MIS has underlined the development, application and validation of relevant theories and models in attempts to encourage quality work in the area. Referring to the literatures, the field of Management Information Systems (MIS) has had a variegated development in its relatively short life span. MIS has developed its own theme of research and studies. Tracing previous literatures, we can report that during its first few decades, MIS concentrated on the information in the context of:

- Electronic data processing which carries out transaction processing functions and records detailed factual data.
- Management reporting systems which scrutinize the operational activities of an organization, providing summaries, information and feedback to management.

Only during the last two decades, the MIS field has shifted to the primary, considered the second type of communication, namely, instruction-based. This has become known as the domain of expert systems [10]. In attempts to review published studies on MIS and articles, Alavi and Carlson [3] have identified popular research topics, the dominant research perspective, and the relationship between MIS research and practice. In contrast, MIS field is examined and a constant shift of MIS research from a technical focus to a technology-organizational and managementsocial focus is found.

Skyrius [12] underlines the decision maker's attitudes towards different factors influencing the quality of business decisions; these factors include information sources, analytical tools, and the role of information technologies. Handzic [5] also pays attention to the impact of information availability on people's ability to process and use information in short and long term planning and in decision making tasks. He revealed that the better the availability of information, the better the impact on both efficiency and accuracy of business decisions. Liu and Young [8] talk about key information models and their relationships in business decision support in three different scenarios. The authors proved that global businesses are in advance due to the Enterprise Applications System provided by modern IT tools such as Enterprise Resource Planning (ERP), Knowledge Management Systems (KMS) and Customer Relations Management (CRM) to enhance the efficiency and effectiveness of the Decision Making process. In order to improve the financial organizational capability and enhance its level of competition in the market, financial organizations should understand the dimensions of the Information Management, and clearly define and develop the resources in case of human, technological, and internal operations, among others, and manage them well across the organizational boundaries. However, establishing the link between Information System Management, planning and decision making is, at best, tricky. In an article by Shu and Strassmann [11], a survey was conducted at 12 banks in the US between 1989 and 1997. They noticed that even though Information Technology had been one of the most essentially dynamic factors relating all efforts, it could not improve banks' earnings. However, conversely, there are many literatures approving the positive impacts of Information Technology expenses on business value. Kozak [6] investigates the influence of the evolution in Information Technology on the profit and cost effectiveness of the banking zone during the period between 1992 and 2003. The study indicates an optimistic relationship among the executed Information Technology, productivity and cost savings. Organizations that do not have formal Information sharing practices will fail to leverage their managers' intellectual capital for business innovation and growth. MIS enables the exchange of experiences, which transfers the required information to the management levels to sustain competitive advantage since it affects the decision making to improve the quality of services provided. Therefore, it is imperative that these organizations continuously motivate their employees to share valuable information so that their intellectual capital can be leveraged. Management Information System will give the banking management a new dimension in managing its knowledge and 
help in carrying out and maximizing the management's initiatives in harmonizing the appropriate strategies in the short and long planning. MIS is indispensable in the area of decision-making as it can monitor by itself the instability in a system, verify a course of action and take action to keep the system in control. Literatures also suggested that non programmed decisions are relevant as they provide support by supplying information to the search, the analysis, the evaluation and the choice and implementation process of decision making. More recently, Adebayo [1] explained that the existence of MIS is needed to improve and enhance decision making on the issues affecting human and material resources.

From the literatures presented, we can easily perceive that the importance of the role of both middle and top management to maintain a consistent approach to develop, use, and evaluate MIS systems within the institution. To financial institutions, MIS is used at various levels by top-management, middle and even by the operational staff as a support for decision making that aims to meet strategic goals and strategic objectives. The above literatures also explore the importance of MIS in providing decision makers with facts, which consequently support and enhance the entire decision-making process. Furthermore, at the most senior level, MIS and DSS supply the data and required information to assist the board of directors and management levels to make an accurate and on time strategic decisions.

\section{ROLE OF MANAGEMENT INFORMATION SYSTEMS}

- Support for business Function (Operations): MIS support business operations by processing data with high speed and more capacity generated by and used in business operations. They record and process data resulting from business transaction database and produce various documents and reports to speed in business operation and hence decision making would be a time.

- Support of management decisions: Management information system plays this role by providing reports and critical information to managers.

- Support of competitive strategic advantage: It achieves these roles by improving operational efficiency of the organization promoting business innovation and building strategic information resource.

- Data and information: According to O'Brien [9] he defined these terms as follows; Data: data is the collection of facts and procedures which are available in the organization it includes customer account number, peoples and etc. they construct available organizational resource it must be managed effectively to benefit uses in the organization. Information: information is the output of data i.e. the processed data in order to achieve organizational objective the available data in the organization must be changed to the necessary information in the form understood by those users.

\subsection{TYPES OF MANAGEMENT INFORMATION SYSTEM}

\subsubsection{Decision Support System (DSS):}

According to O' Brien [9], DSS are computer based information system that provides interactive information support to managers and business professionals during the decision making process.

\subsubsection{Transaction Processing System (TPS):}

TPS are cross sectional system that process data resulting from the occurrence of business transactions.

\subsubsection{Marketing Information System (MKIS):}

The basic goals of the marketing function in any organization are to satisfy the needs and wants of customers to achieve that goal marketing activities.

\subsubsection{Executive Support System (ESS):}

Executive support system help executives organize their interactions with the external environment by providing graphical and communication technologies in accessible places such as board rooms or personal corporate offices.

\section{METHODS}

\subsection{RESEARCH DESIGN}

The researcher was used descriptive research design because it can provide a lot of information and a number of answers to various aspects being studied and it help to capture and explain the details of the study.

\subsection{SAMPLING TECHNIQUE}

The researcher was used census surveys because the population is small and it is necessary to give equal chance to employees and the selection of each spending was clearly known and also this census used to avoid bias.

\subsection{SAMPLE SIZE}

Based on the information given by the managers the total population in the organization was 76 employees. From the total population 39 employees were males and the remaining 37 employees were females. The researcher conducted the study by taking the entire total population.

\subsection{METHOD OF DATA COLLECTION}

To obtain relevant and necessary information, the researcher has used closed ended questionnaires and interview. The reason behind choosing closed ended questionnaire is that it is easy to standardize and are relatively quick and easy to create, code and interpreted which makes the study reliable. The interview parts helped the researcher to obtain some points that were not included in the questionnaire part of the study. 


\section{ANALYSIS}

Seventy six questionnaires were distributed to employees but 8 questionnaires were unreturned by some employees, therefore 68 questionnaires were collected properly.

Table.1. Personal Information of the Respondents

\begin{tabular}{|c|c|c|c|}
\hline Item & Description & $\begin{array}{c}\text { No. of } \\
\text { respondents }\end{array}$ & Percentage \\
\hline \multirow{5}{*}{ Sex } & Male & 36 & $53 \%$ \\
& Female & 32 & $47 \%$ \\
& Total & 68 & $100 \%$ \\
\hline \multirow{5}{*}{ Education } & Grade 12 & 3 & $4.4 \%$ \\
& Certificate & 8 & $11.76 \%$ \\
& Diploma & 15 & $20 \%$ \\
& Degree & 42 & $61.76 \%$ \\
& Above degree & 0 & $0 \%$ \\
& Total & 68 & $100 \%$ \\
\hline \multirow{5}{*}{ Age } & $<30$ & 18 & $25 \%$ \\
& $31-40$ & 38 & $56 \%$ \\
& $41-50$ & 9 & $14 \%$ \\
& 51 above & 3 & $5 \%$ \\
& Total & 68 & $100 \%$ \\
\hline \multirow{5}{*}{ Experience } & $0-3$ year & 6 & $9 \%$ \\
& $3-6$ year & 14 & $20.58 \%$ \\
& $6-9$ year & 20 & $29.42 \%$ \\
& Above & 28 & $41 \%$ \\
& Total & 68 & $100 \%$ \\
\hline
\end{tabular}

Source: Survey Result 2017

According to the Table.1 item 1, male and female respondents were $36(53 \%)$ and $32(47 \%)$ respectively. This implies that the numbers of males are greater than females. From the Table. 1 item 2 , the education of respondents were $3(4.4 \%)$ were $<12,8$ $(11.76 \%)$ were certificate $15(20 \%)$ were diploma, $42(61.76 \%)$ were degree, this shows that most of the employees are above diploma. from the above table of Table. 1 item 4, shows that 18 $(25 \%)$ of the employees were less than the age of $30,38(56 \%)$ were between the age of $3140,9(14 \%)$ were between the age of $30,38(56 \%)$ and $3(5 \%)$ were above the age of 51 . This indicates that most of the employees are greater than the age of 30 . As the Table. 1 of item 4, shows that the experience of the employees were $6(9 \%), 14(20.58 \%) 20(29.42 \%)$ and $28(41 \%)$ for $0-3$ year, 3-6 year, 6-9 years and above respectively. This implies that the majority of the employees were above 9 years' experience. This might help them to understand the role of management information system in the organization.

According to the data presented in the Table.2, 38 (55.88) were employees they say strongly agree in which MIS support decision making process $19(27.94 \%)$ were say agree, $4(5.88 \%)$ were neutral, $5(7.35 \%)$ were disagree and 2 (2.94) were strongly is agree. This indicates that MIS support decision making process.

From the Table.3, 40 (58.82\%) were strongly agree, 19 $(27.94 \%)$ were agree, $2(2.94 \%)$ were neutral, $3(4.4 \%)$ were disagree and $4(5.8 \%)$ were strongly disagree in that MIS enhance organizational effectiveness. This implies that most of employees are strongly agree with that of MIS can enhance organizational effectiveness.
Table.2. MIS support decision making

\begin{tabular}{|c|c|c|}
\hline Item & No. of respondents & Percentage (\%) \\
\hline $\begin{array}{c}\text { Do MIS support } \\
\text { decision making } \\
\text { process? }\end{array}$ & & \\
\hline Strongly agree & 38 & $55.88 \%$ \\
\hline Agree & 19 & $27.94 \%$ \\
\hline Neutral & 4 & $5.88 \%$ \\
\hline Disagree & 5 & $7.35 \%$ \\
\hline Strongly disagree & 2 & $2.94 \%$ \\
\hline Total & 68 & $100 \%$ \\
\hline
\end{tabular}

Source: Survey Result 2017

Table.3. MIS enhance organizational effectiveness

\begin{tabular}{|c|c|c|}
\hline Item & $\begin{array}{c}\text { No. of } \\
\text { respondents }\end{array}$ & $\begin{array}{c}\text { Percentage } \\
(\mathbf{\%})\end{array}$ \\
\hline $\begin{array}{c}\text { Do MIS enhance } \\
\text { organizational } \\
\text { effectiveness? }\end{array}$ & 40 & $55.82 \%$ \\
\hline Strongly agree & 19 & $27.94 \%$ \\
\hline Agree & 2 & $2.94 \%$ \\
\hline Neutral & 3 & $4.4 \%$ \\
\hline Disagree & 4 & $5.8 \%$ \\
\hline Strongly disagree & 68 & $100 \%$ \\
\hline Total & \multicolumn{2}{|c}{} \\
\hline
\end{tabular}

Source: Survey Result 2017

Table.4. Challenges regarding the application of MIS

\begin{tabular}{|c|c|c|}
\hline Item & $\begin{array}{c}\text { No. of } \\
\text { respondents }\end{array}$ & $\begin{array}{c}\text { Percentage } \\
(\mathbf{\%})\end{array}$ \\
\hline $\begin{array}{c}\text { Is there any challenges } \\
\text { regarding the } \\
\text { application of MIS? }\end{array}$ & 50 & $73.6 \%$ \\
\hline Yes & 18 & $26.4 \%$ \\
\hline No & 62 & $100 \%$ \\
\hline Total & \\
\hline
\end{tabular}

Source: Survey Result 2017

As clearly depicted in the Table.4, 50 (73.6\%) of the respondents replied those answers on the questionnaire to the researcher there are prevailing challenges regarding the application of MIS, were as $18(26.4 \%)$ of the respondents replied that there is no challenges regarding the application of MIS. This implies that there are challenges regarding the application of MIS.

Regarding this, those respondents, 5 (7.4\%) replied that the organization challenge is shortage of computer, $30(44.1 \%)$ replied that leak of computer professional, $3(4.4 \%)$ replied that the challenge of the organization is leak of data storage device and $30(44.1 \%)$ replied that shortage of finance. This shows that the organization problems answer from leak of computer professional and shortage of finance to run the business. 
Table.5. Identification of challenges

\begin{tabular}{|c|c|c|}
\hline Item & $\begin{array}{c}\text { No. of } \\
\text { respondents }\end{array}$ & $\begin{array}{c}\text { Percentage } \\
(\%)\end{array}$ \\
\hline $\begin{array}{c}\text { If your answer is "yes" for } \\
\text { question no 3, } \\
\text { What are the challenges? }\end{array}$ & & \\
\hline Shortage of computer & 5 & $7.4 \%$ \\
\hline Lack of computer professional & 30 & $44.1 \%$ \\
\hline Lack of data storage device & 3 & $4.4 \%$ \\
\hline Shortage of finance & 30 & $44.1 \%$ \\
\hline Total & 68 & $100 \%$ \\
\hline
\end{tabular}

Source: Survey Result 2017

Table.6. Level of satisfaction with the role of MIS

\begin{tabular}{|c|c|c|}
\hline Item & $\begin{array}{c}\text { No. of } \\
\text { respondents }\end{array}$ & $\begin{array}{c}\text { Percentage } \\
(\mathbf{\%})\end{array}$ \\
\hline $\begin{array}{c}\text { To what extent you are satisfied } \\
\text { with the role of MIS providing } \\
\text { effectiveness? }\end{array}$ & 8 & $12 \%$ \\
\hline very low & 12 & $17.6 \%$ \\
\hline low & 32 & $47 \%$ \\
\hline moderate & 6 & $8.8 \%$ \\
\hline high & 10 & $14.6 \%$ \\
\hline very high & 68 & $100 \%$ \\
\hline Total & & \\
\hline
\end{tabular}

Source: Survey Result 2017

Table.7. Performance changes after implementation of MIS

\begin{tabular}{|c|c|c|}
\hline Item & $\begin{array}{c}\text { No. of } \\
\text { respondents }\end{array}$ & $\begin{array}{c}\text { Percentage } \\
\mathbf{( \% )}\end{array}$ \\
\hline $\begin{array}{c}\text { Did you agree that appositive } \\
\text { change in your performance after } \\
\text { the implementation of MIS in the } \\
\text { organization? }\end{array}$ & & \\
\hline Yes & 48 & $70.6 \%$ \\
\hline No & 20 & $29.4 \%$ \\
\hline Total & 68 & $100 \%$ \\
\hline
\end{tabular}

Source: Survey Result 2017

From the Table.6, 8 (12\%) replied that the role of MIS in the organization have very low $12(17.6 \%)$ responded that low satisfaction with the role of MIS $32(47 \%)$ replied that moderate, $6(8.8 \%)$ replied that high and the remaining has $10(14.6 \%)$ replied that very high.

The Table.6 shows that the role of MIS has a moderate role in terms of service and of employment growth in the organization. This implies that Debre Markos city administration revenue office employees who are operate the day to day activities in theses organization have moderate satisfaction with the role of MIS to the organization.

From the Table.7, $48(70.6 \%)$ of respondents supports those idea and the remaining $20(29.4 \%)$ replied that MIS have no any contribution to the change in performance. From the data the respondents answer shows that the implementation of MIS has appositive impact and plays a vital role for increasing performance of employees in terms of quality and satisfaction of customers.

Table.8. What are these changes that have seen

\begin{tabular}{|c|c|c|}
\hline Item & $\begin{array}{c}\text { No. of } \\
\text { respondents }\end{array}$ & $\begin{array}{c}\text { Percentage } \\
(\mathbf{\%})\end{array}$ \\
\hline $\begin{array}{c}\text { What are the changes that have } \\
\text { seen in your performance after the } \\
\text { implementation of MIS in the } \\
\text { organization? }\end{array}$ & & \\
\hline Improve efficiency & 18 & $26.47 \%$ \\
\hline Decrease workload & 30 & $44.12 \%$ \\
\hline Increase productivity & 20 & $29.41 \%$ \\
\hline Total & 68 & $100 \%$ \\
\hline
\end{tabular}

Source: Survey Result 2017

According to the Table.8, $18(26.47 \%)$ of the respondents were replied that improve efficiency, 30 (44.12\%) replied decrease workload. And 20 (29.41\%) replied increase productivity. This indicates that decrease work load is changes that have seen in employee's performance after the implementation of MIS in the organization.

Table.9. Automation of current system and its problems

\begin{tabular}{|c|c|c|}
\hline Item & $\begin{array}{c}\text { No. of } \\
\text { respondents }\end{array}$ & $\begin{array}{c}\text { Percentage } \\
(\mathbf{\%})\end{array}$ \\
\hline $\begin{array}{c}\text { To What extent the organization } \\
\text { automates the system to current } \\
\text { global changes? }\end{array}$ & & \\
\hline Low & 20 & $29.42 \%$ \\
\hline Moderate & 40 & $58.82 \%$ \\
\hline High & 8 & $11.76 \%$ \\
\hline Total & 68 & $100 \%$ \\
\hline
\end{tabular}

Source: Survey Result 2017

Table.10. Delay of information

\begin{tabular}{|c|c|c|}
\hline Item & $\begin{array}{c}\text { No. of } \\
\text { respondents }\end{array}$ & $\begin{array}{c}\text { Percentage } \\
(\%)\end{array}$ \\
\hline $\begin{array}{c}\text { How the organization did reply when } \\
\text { the delays of information happen? }\end{array}$ & & \\
\hline Low & 40 & $58.82 \%$ \\
\hline Moderate & 28 & $41.18 \%$ \\
\hline High & 0 & $0 \%$ \\
\hline Total & 68 & $100 \%$ \\
\hline
\end{tabular}

Source: Survey Result 2017

As shows on Table.9, 20 (29.42\%) responded that the organization automation the system to current global changes are low, $40(58.82 \%)$ replied that the organization automates the system is moderate and the remaining $8(11.76 \%)$ responds that the organization automates the system are high. since this idea is 
supported by $58.82 \%$ of respondents evolved in the researcher questionnaire. This indicates that the organization auto mates to current global changes moderately. So the organization should be automating the system.

From the Table.10, 40 (58.82\%) of respondents replied very low $28(41.18 \%)$ answered that the organization moderate when the delay of information occurred, this shows that organization reply very lately when delay of information occurs.

Table.11. Training of employees and use of MIS

\begin{tabular}{|c|c|c|}
\hline Item & $\begin{array}{c}\text { No. of } \\
\text { respondents }\end{array}$ & $\begin{array}{c}\text { Percentage } \\
(\mathbf{\%})\end{array}$ \\
\hline $\begin{array}{c}\text { Did get any training about } \\
\text { how to use MIS in the } \\
\text { organization? }\end{array}$ & 14 & $20.60 \%$ \\
\hline Yes & 54 & $79.40 \%$ \\
\hline No & 68 & $100 \%$ \\
\hline Total &
\end{tabular}

Source: Survey Result 2017

As depicted the Table.11, 14 (26.60\%) of total respondents replied that the organization given training about how to use the systems, the remaining $54(79.40 \%)$ replied that they have not get training. This shows that the organization does not give training about how to use the system. As a result the effectiveness of employees is not increased that much as expected.

Table.12. Problems of MIS

\begin{tabular}{|c|c|c|}
\hline Item & $\begin{array}{c}\text { No. of } \\
\text { respondents }\end{array}$ & $\begin{array}{c}\text { Percentage } \\
(\mathbf{\%})\end{array}$ \\
\hline $\begin{array}{c}\text { What are the problems } \\
\text { currently faced with in the } \\
\text { organization regarding MIS? }\end{array}$ & & \\
\hline Delaying data processing & 37 & $54.40 \%$ \\
\hline Data redundancy & 8 & $11.76 \%$ \\
\hline Data inconsistency & 12 & $17.64 \%$ \\
\hline Information overload & 11 & $16.2 \%$ \\
\hline total & 68 & $100 \%$ \\
\hline
\end{tabular}

Source: Survey Result 2017

Table.13. Decision making

\begin{tabular}{|c|c|c|}
\hline Item & $\begin{array}{c}\text { No. of } \\
\text { respondents }\end{array}$ & $\begin{array}{c}\text { Percentage } \\
(\mathbf{\%})\end{array}$ \\
\hline $\begin{array}{c}\text { Are MIS helps to make } \\
\text { effective decision making? }\end{array}$ & 64 & $94.2 \%$ \\
\hline Yes & 4 & $5.8 \%$ \\
\hline No & 68 & $100 \%$ \\
\hline Total &
\end{tabular}

Source: Survey Result 2017

As depicted from the Table.12. there are problems which affects the organization to run the system effectively as per employees of the organization required depends up to these problems $37(54.40 \%)$ of respondents replied that the organization major problem is comes from delay in data processing $8(11.76 \%)$ responds that the organization problem is a result of data redundancy, $12(17.64 \%)$ replied that the organization problem is arising because of data inconsistency and the remaining 11 $(16.2 \%)$ argued that problems that affect the current system are resulted from information overload This shows that the problem currently affects is delay in data processing.

According to the respondents, that replied Table.13 show that $64(94.2 \%)$ of respondents suggests that MIS plays a vital role for effective decision making and the remaining 4 (5.8\%) of respondents replied that MIS have no any advantage for effective decision making, the above table shows that management information system plays or helps to make effective decision making.

Table.14. Networking of computers

\begin{tabular}{|c|c|c|}
\hline Item & $\begin{array}{c}\text { No. of } \\
\text { respondents }\end{array}$ & $\begin{array}{c}\text { Percentage } \\
(\%)\end{array}$ \\
\hline $\begin{array}{c}\text { Does the organization } \\
\text { networking the application of } \\
\text { computer? }\end{array}$ & & \\
\hline Yes & 16 & $23.53 \%$ \\
\hline No & 52 & $76.47 \%$ \\
\hline Total & 68 & $100 \%$ \\
\hline
\end{tabular}

Source: Survey Result 2017

According to the data presented in the Table.14, 16 (23-53\%) respondents replied that the organization are networking computers and the remaining $52(76.47 \%)$ of respondents replied that the organization are not networking the application of computers. These data shows that the organization does not networked computers.

\section{CONCLUSIONS}

Networking of computer is not enough to delivery of information to the right users. MIS plays a vital role for good decision making through providing relevant, accurate and consistent information to the managers. Concerning the main challenges regarding application of MIS are lack of computer professional and lack of finance to run the business. The application of MIS has its own paramount effect for the increasing operating performance of employees. Concerning the extent employees satisfied with the role of MIS is moderately in day to activities of the organization.

The overall problems of MIS are data redundancy, delaying data processing, data inconsistencies and other problems mostly which affect to run the system effectively is delaying in processing data due to bulky information processed and the existing system cannot accommodate. Since, MIS as a current emerging system of managerial tool for employees. So the employee requires an intensive training about how to use and operate the system. But, the organization is not giving much emphasis requiring to employee training about how to use the system. 


\section{RECOMMENDATIONS}

Networking of computer is essential not only in the organization but also in the country levels so it is better to the organization to apply in each woreda. Since skilled manpower is essential to the given organization, giving of training about how to use MIS is better to solve lack of computer professionals. The existing problems delay in processing data redundancy, data inconsistency would be better solved as soon as possible by design specific procedures and using advanced technology.

The organization is essential by expanding and develops MIS department for developing new system not only request basis for assessing and acquiring new technology, for assessing corporate information need and the like. The organization has successful and it is better than the current decision making process by designed well organized and developed MIS to make appropriate decision making. The organization should give training for employees about how to use management information system.

\section{REFERENCES}

[1] F.A. Adebayo, "Management Information System for Managers", Green Line Publishers, 2007.

[2] Adeoti-Adekeye, "The Importance of Management Information Systems", MCB Bank Library Review, Vol. 46, No. 5, pp. 318-327, 1997.

[3] M. Alavi and P. Carlson, "A Review of MIS Research and Disciplinary Development", Journal of Management Information Systems, Vol. 8, No. 4, pp. 45-62, 1992.

[4] School Management Information Systems and Value for Money. Coventry, Available at: http://39lu337z5111zjr1i1ntpio4.wpengine.netdnacdn.com/wp-content/uploads/2015/05/mis_report_value_money.pdf.

[5] Handzic Meliha, "Does More Information Lead to Better Informing", Available at: http://www.proceedings.informingscience.org/IS2001Proce edings/pdf/hanEBKDoesM.pdf.

[6] S.J. Kozak, "The Role of Information Technology in the Profit and Cost Efficiency Improvements of the Banking Sector", Journal of Academy of Business and Economics, Vol. 5, No. 2, pp. 12-16, 2005.

[7] K.C. Laudon and J.P. Laudon, "Management Information Systems: Managing the Digital Firm”, Pearson, 2015.

[8] S. Liu and R.I.M. Young, "An Exploration of Key Information Models and their Relationships in Global Manufacturing Decision Support", Proceedings of the Institution of Mechanical Engineers, Part B: Journal of Engineering Manufacture, Vol. 21, No. 1, pp. 711-724, 2007.

[9] A. O'Brien, "Management Information System", $7^{\text {th }}$ Edition, McGraw Hill, 1999.

[10] Sasan Rahmatian, "Management Information Systems Education from A Systemic Viewpoint", Systemic Practice and Action Research, Vol. 12, No. 4, pp. 399-408, 1999.

[11] W. Shu and P.A. Strassmann, "Does Information Technology Provide Banks with Profit?", Information and Management, Vol. 42, No. 5, pp. 781-787, 2005.

[12] Rimvydas Skyrius, "A Study on Complex Information Needs in Business Activities", Informing Science: The International Journal of an Emerging Transdiscipline, Vol. 13 , pp. 1-13, 2010 